\title{
Galectin-1 and Galectin-3 in Chronic Pancreatitis
}

\author{
Li Wang, Helmut Friess, Zhaowen Zhu, Luciano Frigeri, Arthur Zimmermann, \\ Murray Korc, Pascal O. Berberat, and Markus W. Büchler
}

Department of Visceral and Transplantation Surgery (LW, HF, ZZ, POB, MWB), University of Bern, Inselspital, Switzerland; and Departments of Medicine, Biological Chemistry, and Pharmacology (MK), University of California, Irvine, and The Scripps Research Institute (LF), La Jolla, California; and Institute of Pathology (AZ), University of Bern, Inselspital, Switzerland

SUMMARY: Galectin-1 and galectin-3 have important functions in cell-cell interactions, cell adhesion to extracellular matrix, the organization of extracellular matrix, and tissue remodeling. To assess their potential role in chronic pancreatitis (CP), we examined their expression by Northern blot analysis, in situ hybridization, immunohistochemistry, and Western blot analysis in normal and CP pancreatic tissues. Northern blot analysis revealed a 4.5-fold increase of galectin-1 mRNA $(p<0.01)$ and a 3.8-fold increase of galectin-3 mRNA $(p<0.01)$ in CP samples compared with normal controls. In situ hybridization analysis of normal pancreas indicated low abundance of galectin-1 mRNA in fibroblasts, whereas galectin-3 mRNA was moderately present in ductal cells. CP samples exhibited moderate to intense galectin-1 mRNA signals in fibroblasts, whereas galectin- 3 mRNA signals were intense in the cells of ductular complexes and weak in the degenerating acinar cells. In addition, intense galectin-1 and galectin-3 mRNA signals were present in nerves of normal and CP samples. Immunohistochemistry showed a distribution pattern of galectin-1 and galectin-3 similar to that described for in situ hybridization. Relative quantification of galectin-1 and galectin-3 protein by immunoblotting revealed an increase of 3.2-fold and 3.0-fold, respectively, in CP compared with normal controls. There was a significant correlation between galectin- 1 and fibrosis and between galectin- 3 and fibrosis and the density of ductular complexes. Up-regulation of galectin-1 in fibroblasts and galectin-3 in ductular complexes suggests a role of these lectins in tissue remodeling in CP. Galectin-1 might participate in ECM changes, whereas galectin-3 seems to be involved in both ECM changes and ductular complex formation. (Lab Invest 2000, 80:1233-1241).

$C$ hronic pancreatitis $(\mathrm{CP})$ is prevalent in most parts of the world. In Western industrialized countries, chronic alcohol ingestion is the main etiologic factor in approximately $80 \%$ of patients with CP (Adler and Schmid, 1997). The typical histomorphologic changes present in CP include acinar cell degeneration and dedifferentiation of acinar cells into duct-like tubular complexes, pseudoductular hyperplasia, enlarged pancreatic ducts, replacement of the functional parenchyma by variable amounts of fibrosis, infiltration by inflammatory cells, and an increase in the size and number of pancreatic nerves, some of which exhibit morphologic changes suggestive of cell damage (Bockman et al, 1988; Korc and Schmiegel, 1994). Although recent studies indicate that various cytokines and growth factors and their receptors are involved in the pathophysiologic processes of $\mathrm{CP}$, the exact biochemical and molecular mechanisms that underlie these changes are still not clear (Kornmann et al, 1998).

Galectins are a family of carbohydrate-binding proteins identified by characteristic amino acid se-

Received March 2, 2000.

This work was supported in part by the DKF research grant, University of Bern, Switzerland, and SNF Grant 32-49494.96, Swiss National Foundation.

Address reprint requests to: Dr. Helmut Friess, Department of Visceral and Transplantation Surgery, University of Bern, Inselspital, CH-3010 Bern, Switzerland.Fax: 4131632 9732; E-mail: helmut.friess@insel.ch quences and an affinity for $\beta$-galactoside sugars on glycoproteins (Barondes et al, 1994a). They are localized in the cell nucleus, in the cytoplasm, on the cell surface, and in the extracellular matrix (ECM) into which they are secreted by certain cell types (Hughes, 1994). Galectins play a role in cell-cell interactions, cell adhesion to the ECM, the organization of ECM, tissue remodeling, RNA splicing/transport, growth regulation, and malignant transformation by binding complimentary glycoconjugates expressed on the surface of adjacent cells, inside the cell, or in the ECM (Barondes et al, 1994b; Leffler, 1997; Matejuk and Dus, 1998). In mammals, at least 10 members of the galectin family are present.

Galectin-1 and galectin-3 are the two most intensively studied members of the galectin family (Leffler, 1997). Recent studies suggested a possible involvement of galectin-1 and galectin-3 in diverse physiologic and pathologic processes, including the regulation of cell growth, cell differentiation, and inflammatory responses (Liu, 1993; Xu et al, 1995). Recently, the presence of galectin-3 immunoreactivity was reported in ductal cells and nerves in CP (Schaffert et al, 1998). However, whether the expression of galectin-3 is also changed at the RNA level and whether galectin-1 is altered in $\mathrm{CP}$ has not been analyzed. Therefore, in the present study the expression and distribution of galectin-1 and galectin-3 mRNA and protein in CP were studied by Northern blot analysis, in situ hybridization, immunohistochem- 
istry, and Western blot analysis to reveal their potential function in the organization of ECM and tissue remodeling in this disorder.

\section{Results}

\section{Northern Blot Analysis}

Northern blot analysis revealed the presence of a single galectin-1 and galectin-3 mRNA transcript in all normal and CP tissue samples (Fig. 1). The transcript size was approximately $0.5 \mathrm{~kb}$ for galactin-1 mRNA and $1.1 \mathrm{~kb}$ for galectin-3 mRNA. Galectin-1 and galectin-3 mRNA levels were increased in 21 of 31 (68\%) and 20 of 31 (65\%) of the CP samples, respectively, compared with normal controls. Quantification of the mRNA signals revealed that galectin-1 mRNA levels increased 4.5 -fold $(p<0.01)$ and galectin-3 mRNA levels increased 3.8-fold ( $p<0.01$ ) when all of the CP samples were compared with normal controls. When only CP samples with increased galectin-1 and galectin-3 mRNA expression were evaluated, the increases were 6.8-fold $(p<0.01)$ and 6.2-fold $(p<$ $0.01)$, respectively. In 18 of 31 (58\%) CP samples, concomitant overexpression of galectin-1 and galectin-3 was present, and in $5 \mathrm{CP}$ samples, the expression of galectin-1 and galectin- 3 was not simultaneously increased. In CP samples with concomitant enhanced expression of galectin-1 and galectin-3, the increases were 6.4-fold and 6.0-fold, respectively. Furthermore, there was a positive correlation between the expression levels of galectin-1 and galectin-3 mRNA $(r=0.84, p<0.01)$ in CP samples.

\section{In Situ Hybridization}

In the normal pancreas, galectin-1 mRNA signals were weakly present only in the cytoplasm of fibroblasts. Acinar and ductal cells did not exhibit any galectin-1 mRNA signals (Fig. 2A; Table 1). Galectin-3 mRNA

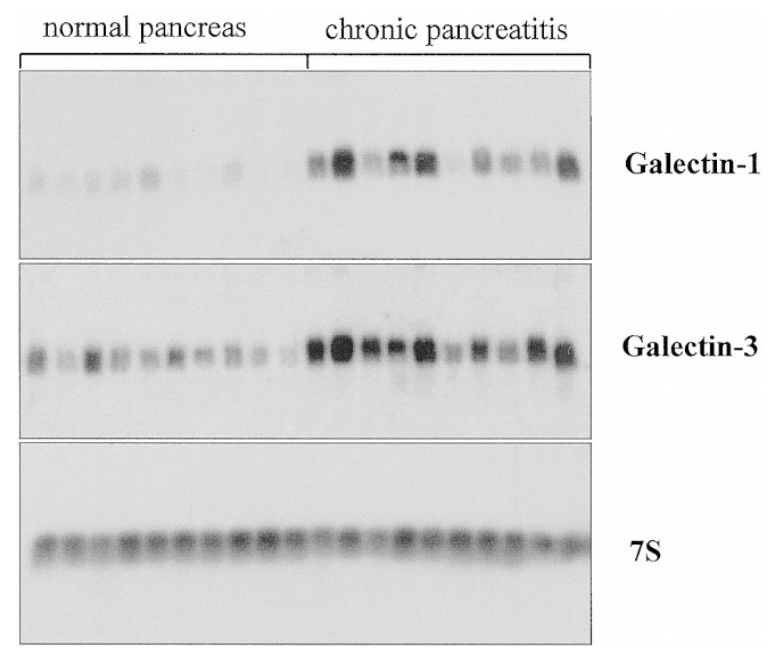

\section{Figure 1.}

Northern blot analysis of galectin- 1 and galactin- 3 in the normal pancreas and chronic pancreatitis (CP). Galectin-1 and galactin-3 mRNA signals were increased in most CP samples compared with normal controls. signals were present in moderate levels only in the cytoplasm of ductal cells, but were absent in acinar cells and in fibroblasts (Fig. 2B; Table 1).

In CP samples, galectin-1 mRNA signals were moderately to intensely present in the cytoplasm of fibroblasts. Degenerating acinar cells and cells of ductular complexes were devoid of any galectin-1 mRNA expression (Fig. 2C; Table 1). In contrast, galectin-3 mRNA signals were weakly present in the cytoplasm of degenerating acinar cells and intensely present in the cytoplasm of cells of ductular complexes. However, no galectin-3 mRNA signals were present in fibroblasts (Fig. 2D; Table 1).

Furthermore, galectin-1 and galectin-3 mRNA signals were intensely present in nerves in the normal pancreas and in the enlarged nerves in CP (Fig. 2, C and $D$, inserts; Table 1). In the normal pancreas and $\mathrm{CP}$, islets were devoid of any galectin- 1 and galectin-3 mRNA staining (Table 1).

\section{Immunohistochemistry}

In the normal pancreas, weak cytoplasmic galectin-1 immunostaining was present in fibroblasts, and galectin-1 immunostaining was absent in acinar and ductal cells (Fig. 3A; Table 1). Galectin-3 immunostaining was present in moderate intensity in the cytoplasm of ductal cells and was absent in acinar cells and from fibroblasts (Fig. 3B; Table 1).

In CP samples, intense galectin-1 immunostaining was observed in the cytoplasm of fibroblasts and was absent in degenerating acinar cells and in cells of ductular complexes (Fig. 3, C and E; Table 1). Weak cytoplasmic galectin-3 immunostaining was present in the degenerating acinar cells and intense immunoreactivity was present in the cytoplasm of cells of ductular complexes. Fibroblasts were devoid of galectin-3 immunoreactivity (Fig. 3, D and F; Table 1). Thus galectin-1 and galectin-3 immunoreactivity closely paralleled their expression, as determined by in situ hybridization.

Intense galectin-1 and galectin-3 immunoreactivity was also present in nerves in the normal pancreas and in CP samples (Fig. 3, C and D, inserts; Table 1). Islets in the normal pancreas and CP samples did not exhibit any galectin-1 or galectin-3 immunostaining (Table 1).

Semiquantitative analysis of galectin-1 and galectin-3 immunohistochemical staining revealed results similar to those determined by Northern blot analysis. Galectin-1 and galectin-3 were concomitantly increased in 18 of 31 (58\%) CP samples. There was a positive relationship between the immunohistochemical staining score of galectin-1 and galectin-3 $(r=0.76, p<0.01)$.

\section{Western Blot Analysis}

To quantify the increase of galectin-1 and galectin-3 in CP samples, Western blot analysis was performed. In the normal pancreas and in CP samples, one protein band of galectin-1 (14.5 kDa) (Cindolo et al, 1999) and three bands of galectin-3 (weight range, 30-35 kDa) 

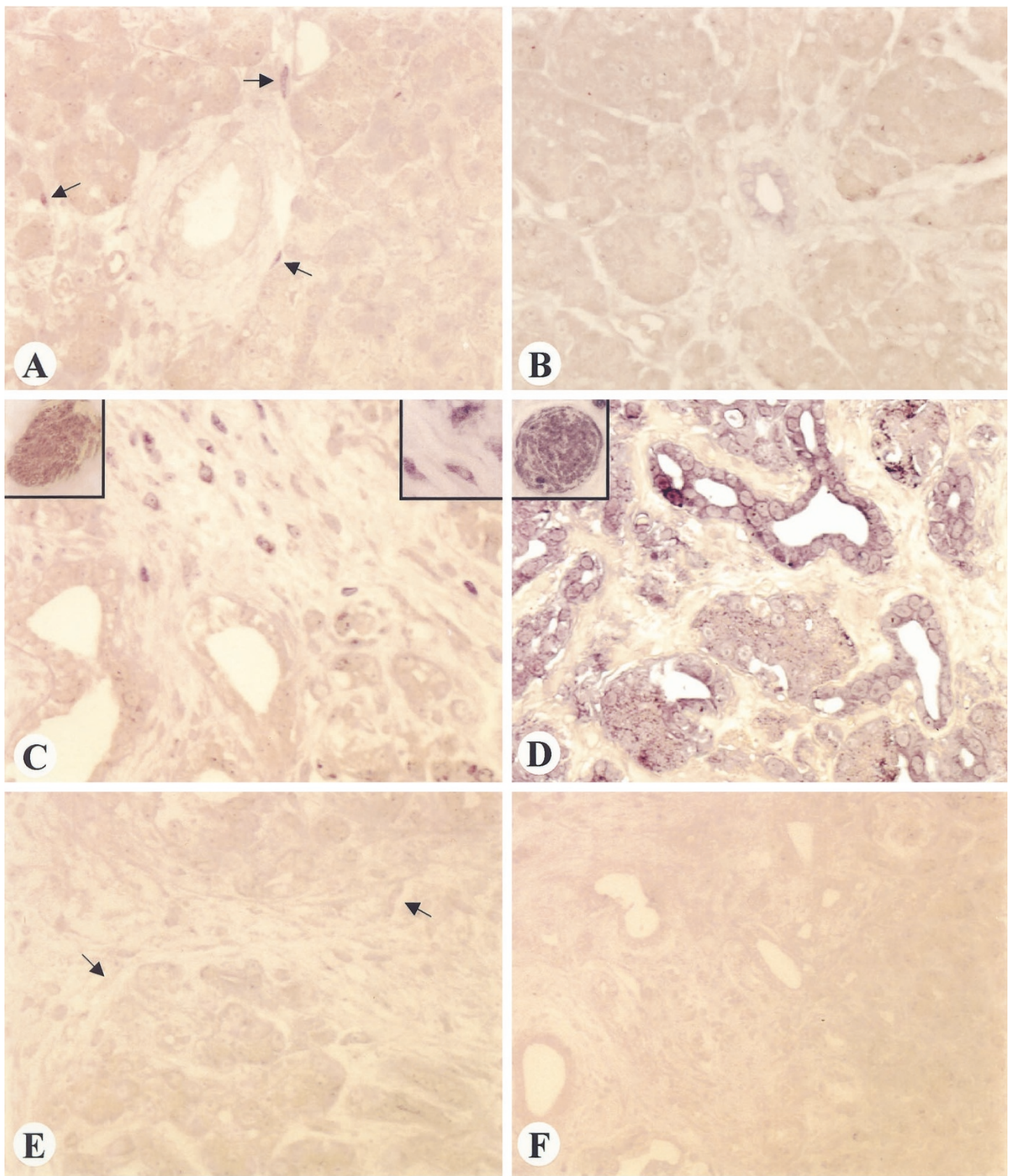

\section{Figure 2.}

In situ hybridization. A, In the normal pancreas, galectin-1 mRNA was weakly present in some fibroblasts (arrows) and absent in ductal and acinar cells. B, Galectin-3 mRNA was moderately present in ductal cells in the normal pancreas. C, In CP, galectin-1 mRNA was moderately to intensely present in fibroblasts (insert, upper right) and in enlarged pancreatic nerves (insert, upper left). D, In contrast, galectin-3 was intensely present in ductular complexes (D) and in nerves (insert) and weakly present in degenerating acinar cells of $\mathrm{CP}$ samples (D). E, In situ hybridization in CP using the sense probe for galectin-1, and $\mathrm{F}$, galectin-3. Arrows in $\mathrm{E}$ indicate fibroblasts. $A$ to $D, C$ upper-left insert, $D$ insert, $E$, and $F$, original magnification, $\times 200$; $C$ right-upper insert, original magnification, $\times 400$.

were present, as previously described for other tissues (Fig. 4) (Schaffert et al, 1998). Quantification of the Western blot results by densitometry revealed a 3.2-fold increase $(p<0.01)$ and a 3.0-fold increase $(p<0.01)$ of galectin-1 and galectin-3 protein levels, respectively.

\section{Correlation of Galectin-1 and Galectin-3 with Morphologic Changes}

The immunohistochemical staining score of galectin-1 and galectin-3 was correlated with the extent of pancreatic fibrosis and the density of ductular complexes 
Table 1. The Distribution and Intensity of Galectin-1 and Galectin-3 mRNA and Proteins in the Normal Pancreas and in Chronic Pancreatitis

\begin{tabular}{|c|c|c|c|c|c|c|c|c|c|c|}
\hline & \multicolumn{5}{|c|}{ Normal pancreas } & \multicolumn{5}{|c|}{ Chronic pancreatitis } \\
\hline & $\begin{array}{l}\text { Acinar } \\
\text { cells }\end{array}$ & $\begin{array}{l}\text { Ductal } \\
\text { cells }\end{array}$ & Fibroblasts & Nerves & Islets & $\begin{array}{l}\text { Acinar } \\
\text { cells }\end{array}$ & $\begin{array}{c}\text { Ductular } \\
\text { complexes }\end{array}$ & Fibroblasts & Nerves & Islets \\
\hline \multicolumn{11}{|c|}{ In situ hybridization } \\
\hline Galectin-1 & - & - & + & +++ & - & - & - & +++ & +++ & - \\
\hline Galectin-3 & - & ++ & - & +++ & - & + & +++ & - & +++ & - \\
\hline \multicolumn{11}{|c|}{ Immunostaining } \\
\hline Galectin-1 & - & - & + & +++ & - & - & - & +++ & +++ & - \\
\hline Galectin-3 & - & ++ & - & +++ & - & + & +++ & - & +++ & - \\
\hline
\end{tabular}

$-=$ no staining; $+=$ weak staining $++=$ moderate staining $+++=$ intense staining.

in CP. Galectin-1 mRNA expression correlated positively with the extent of fibrosis in CP $(r=0.76, p<$ 0.01 ), but was not related to the number of ductular complexes $(r=0.35, p>0.05)$. In contrast, galectin-3 was positively correlated with both the extent of fibrosis $(r=0.67, p<0.01)$ and the number of ductular complexes $(r=0.78, p<0.01)$ (Fig. 5).

\section{Discussion}

The typical morphologic changes in CP are characterized by the increase of ECM associated with the degeneration and atrophy of the acinar cells. In some areas of $\mathrm{CP}$, acinar cells dedifferentiate into tubular complexes, and these regions appear biologically as an accumulation of pancreatic ducts. The terminology used for these morphologic structures is not uniform; they are described as ductal metaplasia, ductal proliferation, or ductular complexes. Previous studies revealed that areas with ductular complexes seem to play an important role in the process of tissue remodeling and fibrogenesis. Analysis of the epidermal growth factor receptor, c-erbB2, c-erbB3, acidic fibroblast growth factor, basic fibroblast growth factor, transforming growth factor beta, and urokinase plasminogen activator and its receptor revealed that these factors are markedly overexpressed in the ductular complexes of $\mathrm{CP}$, and that the expression levels are much higher in ductular complexes than in degenerating or atrophic acinar cells (Friess et al, 1994, 1997; Korc et al, 1994). These observations suggest that ductular complexes play a specific role in the molecular alterations in CP and that these cells are the major source of growth factors that are related to fibrogenesis.

In the present study, galectin-1 and galectin-3, which influence the organization of ECM and tissue remodeling, exhibited a differential pattern of distribution in CP. Galectin-1 was markedly increased in fibroblasts, whereas galectin-3 was mainly present in degenerating acinar cells and ductular complexes; these results are similar to the previous study (Schaffert et al, 1998). These findings indicate that various galectins may possess different functions in tissue remodeling and fibrogenesis in CP. Enhanced expression of galectin-1 exclusively in fibroblasts in $\mathrm{CP}$ tissues strongly suggests that it is involved in and influences the functions of fibroblasts, as has been suggested for thyroid tissues (Xu et al, 1995). In contrast, because galectin-3 was strongly present in ductular complexes and to a lesser extent in the degenerating acinar cells, it might exert paracrine effects on surrounding fibroblasts, including the modulation of their proliferative capacity. Similar mitogenic capabilities were reported for galectin-3 after fibroblast proliferation was stimulated in a paracrine fashion through interaction with cell-surface glycoconjugates of normal human IMR-90 lung fibroblasts (Inohara et al, 1998).

Because galectin-3 possesses proliferation and tissue remodeling effects (Hughes, 1994; Sasaki et al, 1999), enhanced expression of galectin-3 in ductular complexes suggests that it might contribute to the dedifferentiation of acinar cells into ductular complexes and to ductal cell proliferation, thereby influencing pancreatic remodeling.

The presence of high levels of galectin- 1 and galectin-3 in pancreatic nerves was another observation of our study. Galectin-1 and its laminin ligand have been implicated in the growth of primary sensory olfactory axons arising from the olfactory neuroepithelium that lines the nasal cavity and then projects, via the olfactory nerve, into the olfactory bulb (TenneBrown et al, 1998). Furthermore, galectin-3 influences cell growth and repair in the nervous system by promoting neural cell adhesion and neurite growth (Pesheva et al, 1998). It is expressed in the developing notochord of embryonic mice, and in the dorsal root ganglion of rats with peripheral nerve injury (Cameron et al, 1993; Fowlis et al, 1995). Because in CP, pancreatic nerves are enlarged and their perineurium is frequently damaged, galectins may also be important for the growth and injury protection of the nerves in CP. Inasmuch as galectin-1 is able to selectively eliminate activated $\mathrm{T}$ lymphocytes by inducing apoptosis, and because in $\mathrm{CP}$, enlarged pancreatic nerves are frequently surrounded by inflammatory cells that seem to destroy the perineurium and infiltrate into the injured nerves (Perillo et al, 1995; Rabinovich et al, 1998), intense galectin-1 expression in pancreatic nerves may contribute to the protection of the nerves against inflammatory attacks. 

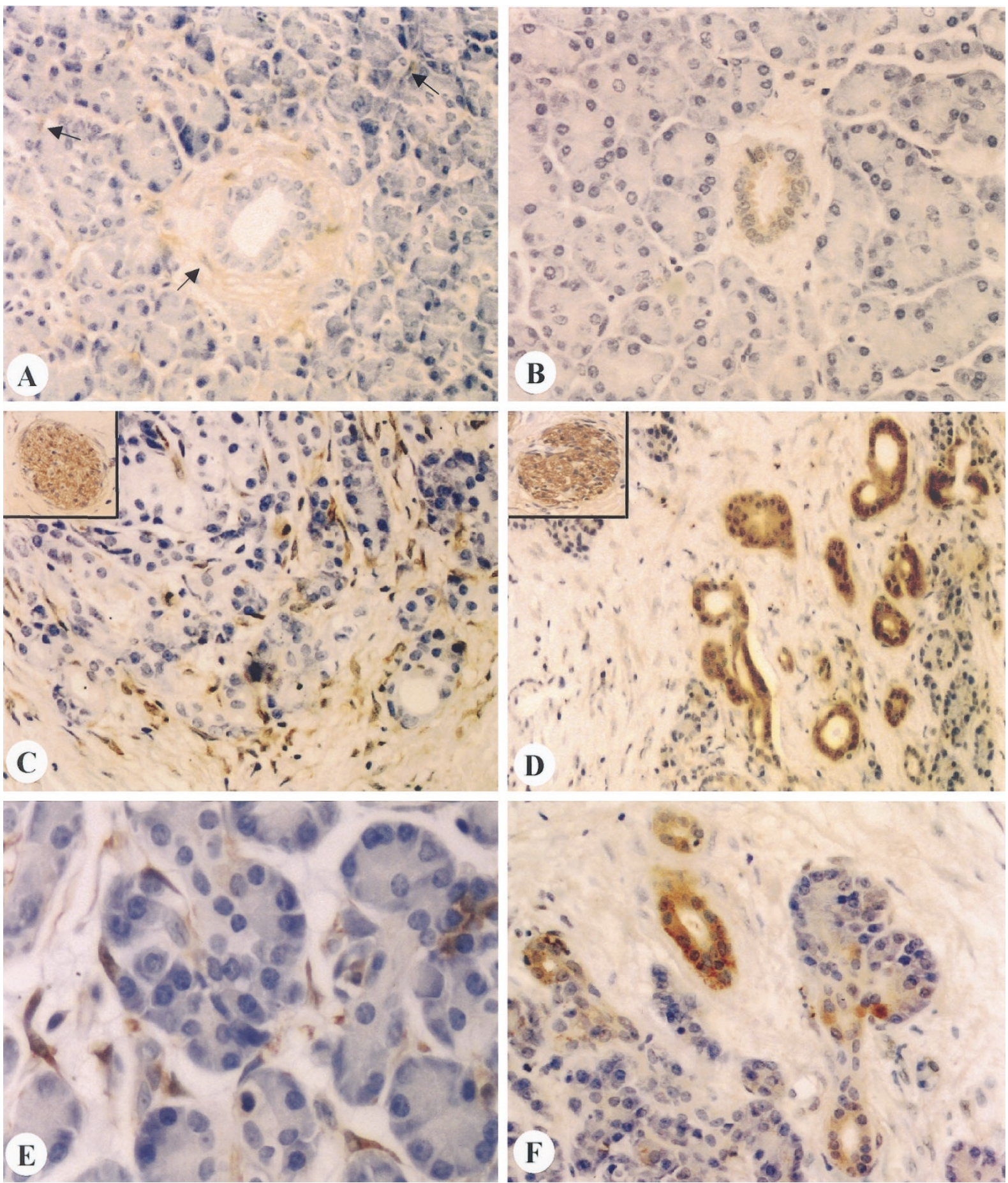

\section{Figure 3.}

Immunohistochemical staining. A, In the normal pancreas, galectin-1 was weakly present in some fibroblasts (arrows) and absent in ductal and acinar cells. B, Moderate galectin-3 immunostaining was present in ductal cells in the normal pancreas. $\mathrm{C}$ and $\mathrm{E}$, In $\mathrm{CP}$, galectin-1 was intensely present in fibroblasts and nerves (C insert). $D$ and $F$, Galectin-3 was intensely present in cells of ductular complexes and weakly present in degenerating acinar cells of the CP samples. $D$ insert, Pancreatic nerves also exhibited intense galectin-3 immunostaining. A to C, C insert, D insert, and F, original magnification, $\times 200$; D original magnification, $\times 100$; and $E$ original magnification, $\times 400$.

In summary, galectin-1 and galectin- 3 are implicated in diverse physiologic and pathologic processes, including in the human pancreas. Enhanced expression of galectin-1 seems to be related to fibrosis, whereas galectin-3 seems to be involved not only in fibrogenesis, but also in the dedifferentiation of acinar cells into ductular complexes. 


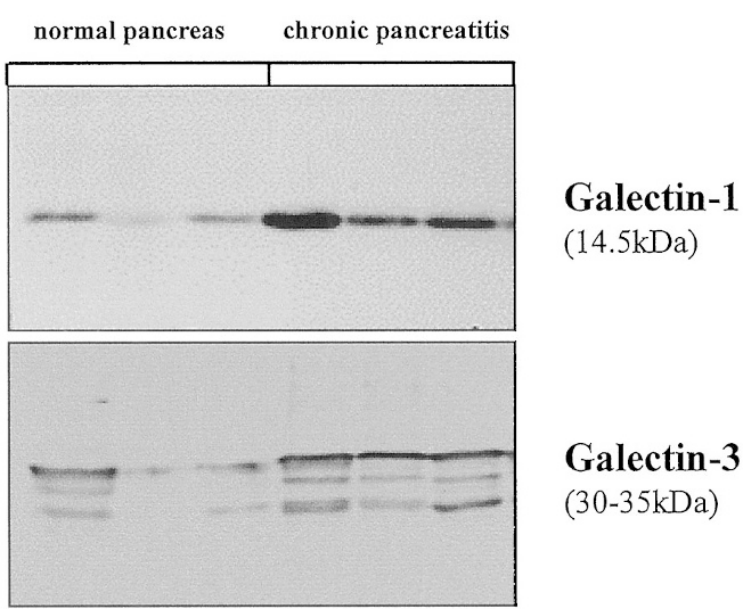

Figure 4.

Western blot analysis. In normal and CP samples, one galectin-1 and three galectin-3 bands were detectable. Galectin-1 and galectin-3 were increased in CP samples compared with normal controls.

\section{Materials and Methods}

\section{Surgical Specimens}

Normal human pancreatic tissue samples were obtained through an organ donor program from 25 individuals (12 women and 13 men; median age, 56 years; range, 25-72 years) who were free of any pancreatic disease. The CP tissue samples were obtained from 31 patients ( 6 women and 25 men; median age, 48 years; range, 34-67 years) who were undergoing pancreatic resection due to alcoholic CP.

The pancreatic tissue samples were immediately fixed in paraformaldehyde and Bouin's solution for 12 to 24 hours and embedded in paraffin for in situ hybridization and immunohistochemistry. Concomitantly, tissue samples for RNA and protein extraction were immediately snap frozen in liquid nitrogen and maintained at $-80^{\circ} \mathrm{C}$ until use. The study was approved by the Human Subject Committee of the University of Bern.

\section{Northern Blot Analysis}

The procedures used have been previously described (di Mola et al, 1999; Friess et al, 1998). Briefly, after extraction and electrophoresis, total RNA was electrotransferred onto nylon membranes. After prehybridization, hybridization was performed in the presence of $1 \times 10^{6} \mathrm{cpm} / \mathrm{ml}$ of the ${ }^{32} \mathrm{P}$-labeled galectin- 1 or galectin-3 antisense cRNA probes. To assess equivalent RNA loading and transfer, all blots were rehybridized with a mouse 7S cDNA probe, which crosshybridizes with human 7S RNA, as previously described. All blots were exposed to x-ray films for 1 to 10 days. For optical density analysis, Image-Pro Plus software (Version 3.1; Media Cybernetics, Silver Spring, Maryland) was used.

\section{In Situ Hybridization}

In situ hybridization was performed as previously described (Guo et al, 1996; Kleeff et al 1998; Lu et al, 1997). The samples were prehybridized and then hybridized with medium containing digoxigeninlabeled sense and antisense galectin-1 $(0.5 \mathrm{ng} / \mu \mathrm{l})$ and galectin-3 probes $(0.5 \mathrm{ng} / \mu \mathrm{l})$. The intensity of the mRNA signals was semiquantitatively recorded, as previously described (Guo et al, 1996), as no staining, weak staining, moderate staining, and intense staining. For control experiments, the slides were incubated with either RNase or the corresponding sense probes. Pretreatment of the slides with RNase or hybridization with sense probes failed to produce in situ hybridization signals.

\section{cRNA and cDNA Probe Synthesis}

Human galectin-1 (225 bp) and galectin-3 (353 bp) cDNAs were generated by RT-PCR. The fragments were subcloned into the PGEM-T Easy vector (Promega Biotechnology, Madison, Wisconsin) and sequenced by the dye terminator method (ABI 373A, Perkin Elmer, Rotkreuz, Switzerland). A 190-bp 7S cDNA that cross-hybridizes with human $7 S$ was subcloned into the pGEM7ZF $(+)$ vector (Promega Biotechnology). For Northern blot analysis, galectin-1 and galectin-3 antisense cRNA probes were radiolabeled with [alpha- ${ }^{32} \mathrm{P}$ ] CTP (Du Pont International, Regensdorf, Switzerland), and the 7S-cDNA probe was labeled with [alpha- ${ }^{32} \mathrm{P}$ ] dCTP (Du Pont). For in situ hybridization, galectin-1 and galectin-3 cRNA sense and antisense probes were labeled with digoxigenin (Lu et al, 1997).

\section{Immunohistochemistry}

Immunohistochemical analysis was performed with the streptavidin-peroxidase technique, as previously described (Friess et al, 1998; Lu et al, 1997). Polyclonal rabbit anti-galectin-1 antibodies for immunohistochemistry $(0.5 \mathrm{ng} / \mathrm{ml})$ were kindly supplied by Dr. Douglas N. W. Cooper (Langley Porter Psychiatric Institute, University of California, San Francisco, California). For immunohistochemistry $(5 \mathrm{ng} / \mathrm{ml})$ of galectin-3, polyclonal rabbit anti-galectin-3 antibodies were used. The specificity of these antibodies has been previously confirmed (Cooper and Barondes, 1990; Frigeri and Liu, 1992). The intensity of the immunostaining was recorded as previously reported as no staining, weak staining, moderate staining, and intense staining. The percentage of immunoreactive cells was also determined. An immunohistochemical staining score for each specimen was calculated and recorded by multiplying the intensity score by the mean percentage of immunohistochemically positive cells, as previously described (Bresalier et al, 1997) (Fig. 5).

\section{Western Blot Analysis}

Approximately $200 \mathrm{mg}$ of tissue samples was powdered in liquid nitrogen and homogenized in lysis 


\section{Galectin-1}
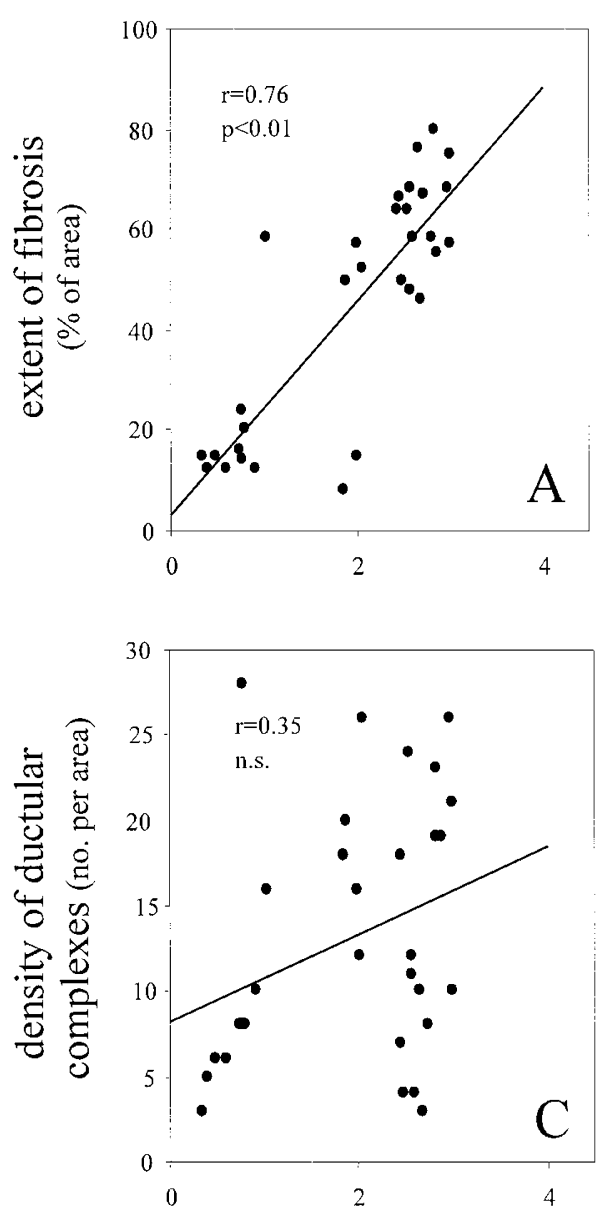

\section{Galectin-3}
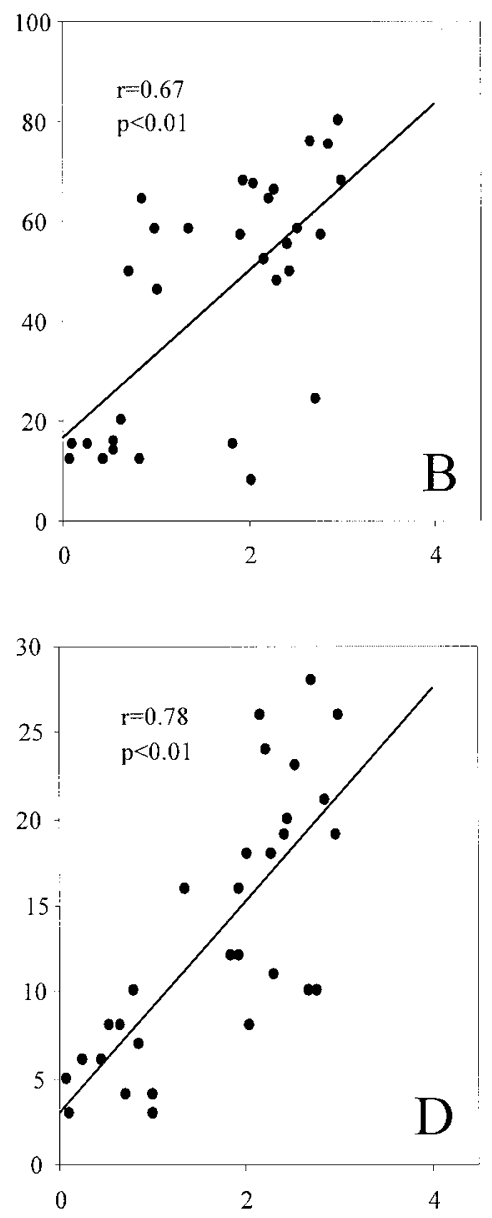

\section{Immunohistochemical staining score}

\section{Figure 5.}

Relationship between the immunohistochemical staining scores of galectin-1 and galectin-3 and the extent of fibrosis (A and $B$ ), and between the immunohistochemical staining scores and the number of ductular complexes ( $C$ and $D)$.

buffer (150 mmole/L NaCl, 10 mmole/L Tris-HCl; pH 7.5) supplemented with a protease inhibitor cocktail (Roche Diagnostics, Rotkreuz, Switzerland). The lysate was collected and centrifuged at $4^{\circ} \mathrm{C}$ for 30 minutes to remove the nonsoluble material. The protein concentration of the supernatants were measured by spectrophotometry using the BCA protein assay (Pierce, Rockford, Illinois). From each sample, $40 \mu \mathrm{g}$ of protein was separated on $12 \%$ (galectin-1) and $7 \%$ (galectin-3) SDS-polyacrylamide gels and electroblotted onto nitrocellulose membranes.

Nitrocellulose membranes were incubated in blocking solution (5\% non-fat milk in 20 mM Tris- $\mathrm{HCl}, 150$ $\mathrm{mm} \mathrm{NaCl,} \mathrm{0.1 \%} \mathrm{Tween-20} \mathrm{[TBS-T]),} \mathrm{followed} \mathrm{by} \mathrm{incu-}$ bation with the anti-galectin-1 $(0.01 \mu \mathrm{g} / \mathrm{ml})$ or antigalectin-3 $(0.5 \mu \mathrm{g} / \mathrm{ml})$ antibodies (the same antibodies that were used for immunohistochemistry) for 1 hour at room temperature. The membranes were then washed with TBS-T and incubated with a horseradish peroxidase conjugated donkey anti-rabbit IgG (1:5000 dilution) for 30 minutes at room temperature. Antibody detection was performed with an enhanced chemiluminescence reaction (ECL Western blotting detection, Amersham Life Science, Amersham, United Kingdom).

\section{Histopathologic Analysis of Tissue Sections}

The extent of fibrosis was assessed by video image analysis. Briefly, a high-resolution color video camera XC-003P (Sony, Tokyo, Japan) was connected to a light microscope (Leica, Bensheim, Germany). For video image analysis, Image-Pro Plus software (Version 3.1, Media Cybernetics) was used. The percentage of fibrosis and the density of ductular complexes (the number of ductular complexes per area [100x]) were recorded (Fig. 5). At least 10 randomly selected areas per slide were checked. 


\section{Statistical Analysis}

Results are expressed as median and range. For statistical analyses, the Mann-Whitney $U$ test and the Spearman correlation analysis were used. $p$-values $<0.05$ were defined as significant.

\section{Acknowledgement}

We would like to thank Dr. Douglas N. W. Cooper, Langley Porter Psychiatric Institute, University of California, San Francisco, California, for providing us with his galectin-1 antibodies for immunohistochemistry and Western blot analysis. We would also like to thank Dr. Hans Graber, Department of Visceral and Transplantation Surgery, University of Bern, for designing the primers for the galectin-1 and galectin-3 cDNA probes.

\section{References}

Adler G and Schmid RM (1997). Chronic pancreatitis: Still puzzling? Gastroenterology 112:1762-1765.

Barondes SH, Castronovo V, Cooper DN, Cummings RD, Drickamer K, Feizi T, Gitt MA, Hirabayashi J, Hughes C, and Kasai K (1994a). Galectins: A family of animal betagalactoside-binding lectins. Cell 76:597-598.

Barondes SH, Cooper DN, Gitt MA, and Leffler H (1994b). Galectins: Structure and function of a large family of animal lectins. J Bio Chem 269:20807-20810.

Bockman DE, Büchler M, Malfertheiner P, and Beger HG (1988). Analysis of nerves in chronic pancreatitis. Gastroenterology 94:1459-1469.

Bresalier RS, Yan PS, Byrd JC, Lotan R, and Raz A (1997). Expression of the endogenous galactose-binding protein galectin-3 correlates with the malignant potential of tumors in the central nervous system. Cancer 80:776-787.

Cameron AA, Dougherty PM, Garrison CJ, Willis WD, and Carlton SM (1993). The endogenous lectin RL-29 is transynaptically induced in dorsal horn neurons following peripheral neuropathy in the rat. Brain Res 620:64-71.

Cindolo L, Benvenuto G, Salvatore P, Pero R, Salvatore G, Mirone V, Prezioso D, Altieri V, Bruni CB, and Chiariotti L (1999). Galectin-1 and galectin-3 expression in human bladder transitional-cell carcinomas. Int J Cancer 84:39-43.

Cooper DN and Barondes SH (1990). Evidence for export of a muscle lectin from cytosol to extracellular matrix and for a novel secretory mechanism. J Cell Biol 110:1681-1691.

di Mola FF, Friess H, Martignoni ME, Di Sebastiano P, Zimmermann A, Innocenti P, Graber H, Gold LI, Korc M, and Büchler MW (1999). Connective tissue growth factor is a regulator for fibrosis in human chronic pancreatitis. Ann Surg 230:63-71.

Fowlis D, Colnot C, Ripoche MA, and Poirier F (1995). Galectin-3 is expressed in the notochord, developing bones, and skin of the postimplantation mouse embryo. Dev Dyn 203:241-251.

Friess H, Cantero D, Graber H, Tang WH, Guo X, Kashiwagi M, Zimmermann A, Gold L, Korc M, and Büchler MW (1997). Enhanced urokinase plasminogen activation in chronic pancreatitis suggests a role in its pathogenesis. Gastroenterology 113:904-913.
Friess H, Lu Z, Graber HU, Zimmermann A, Adler G, Korc M, Schmid RM, and Büchler MW (1998). bax, but not bcl-2, influences the prognosis of human pancreatic cancer. Gut 43:414-421.

Friess H, Yamanaka Y, Büchler M, Beger HG, Do DA, Kobrin MS, and Korc M (1994). Increased expression of acidic and basic fibroblast growth factors in chronic pancreatitis. Am J Pathol 144:117-128.

Frigeri LG and Liu FTJ (1992). Surface expression of functional IgE binding protein, an endogenous lectin, on mast cells and macrophages. J Immunol 148:861-867.

Guo X, Friess H, Graber HU, Kashiwagi M, Zimmermann A, Korc M, and Büchler MW (1996). KAl1 expression is upregulated in early pancreatic cancer and decreased in the presence of metastases. Cancer Res 56:4876-4880.

Hughes RC (1994). Mac-2: A versatile galactose-binding protein of mammalian tissues. Glycobiology 4:5-12.

Inohara H, Akahani S, and Raz A (1998). Galectin-3 stimulates cell proliferation. Exp Cell Res 245:294-302.

Kleeff J, Ishiwata T, Kumbasar A, Friess H, Büchler MW, Lander AD, and Korc M (1998). The cell-surface heparan sulfate proteoglycan glypican-1 regulates growth factor action in pancreatic carcinoma cells and is overexpressed in human pancreatic cancer. J Clin Invest 102:1662-1673.

Korc M and Schmiegel W (1994). Chronic pancreatitis. Curr Opin Gastroenterol 10:502-506.

Korc M, Friess H, Yamanaka Y, Kobrin MS, Büchler M, and Beger HG (1994). Chronic pancreatitis is associated with increased concentrations of epidermal growth factor receptor, transforming growth factor alpha, and phospholipase C gamma. Gut 35:1468-1473.

Kornmann M, Beger HG, and Korc M (1998). Role of fibroblast growth factors and their receptors in pancreatic cancer and chronic pancreatitis. Pancreas 17:169-175.

Leffler H (1997). Introduction to galectins. Trends Glycosci Glycotechnol 9:9-19.

Liu FT (1993). S-type mammalian lectins in allergic inflammation. Immunol Today 14:486-490.

Lu Z, Friess H, Graber HU, Guo X, Schilling M, Zimmermann A, Korc M, and Büchler MW (1997). Presence of two signaling TGF-beta receptors in human pancreatic cancer correlates with advanced tumor stage. Dig Dis Sci 42:2054-2063.

Matejuk A and Dus D (1998). Animal lectins: Structure and function. Postepy Hig Med Dosw 52:445-470.

Perillo NL, Pace KE, Seilhamer JJ, and Baum LG (1995). Apoptosis of T cells mediated by galectin-1. Nature 378:736739.

Pesheva P, Kuklinski S, Schmitz B, and Probstmeier R (1998). Galectin-3 promotes neural cell adhesion and neurite growth. J Neurosci Res 54:639-654. 
Rabinovich GA, Iglesias MM, Modesti NM, Castagna LF, Wolfenstein-Todel C, Riera CM, and Sotomayor CE (1998). Activated rat macrophages produce a galectin-1-like protein that induces apoptosis of T cells: Biochemical and functional characterization. J Immunol 160:4831-4840.

Sasaki S, Bao Q, and Hughes RC (1999). Galectin-3 modulates rat mesangial cell proliferation and matrix synthesis during experimental glomerulonephritis induced by antiThy1.1 antibodies. J Pathol 187:481-489.

Schaffert C, Pour PM, and Chaney WG (1998). Localization of galectin-3 in normal and diseased pancreatic tissue. Int $J$ Pancreatol 23:1-9.
Tenne-Brown J, Puche AC, Key B (1998). Expression of galectin-1 in the mouse olfactory system. Int $\mathrm{J}$ Dev Biol 42:791-799.

Xu XC, el-Naggar AK, and Lotan R (1995). Differential expression of galectin-1 and galectin-3 in thyroid tumors. Potential diagnostic implications. Am J Pathol 147:815-822. 